\title{
The renaissance will not be televised
}

\author{
Angelika Papadopoulos RMIT University, Australia
}

\begin{abstract}
INTRODUCTION: Brave new social landscapes painted in the watercolours of liquid modernity challenge the possibility of a renaissance of radical social work. The consequences of modernity's liquefaction for the project of taking a political stance challenge radical social work conceived as a retrieval of solidarities and mobilised collectives of the past.

APPROACH: Principles of radical analysis are used to explore theoretical and institutional factors affecting the contemporary articulation of a radical project, and to consider the implications of liquid modernity for such an articulation.

CONCLUSION: Radical strategy can no longer take the form of "speaking truth to power", for power no longer feels obliged to listen. Future radical social work can succeed through the creation of new strategic responses to reconstituted fields of practice, state-global interfaces, and the injustices they create. This entails a critical reappraisal of the language of radical practice, a reorientation to the dynamics of new social landscapes and a reframing of the radical position.
\end{abstract}

KEYWORDS: radical social work; liquid modernity; social justice

How do you know that we are leaving modernity? How would one know this anyway, assuming that things like them beginnings or ends of eras - are at all knowable to insiders, people who live through it? (Bauman \& Bordoni, 2014, p. 73)

...the way up and the way down are one and the same. (Heraclitus, fragment 60)

If, by "renaissance", we mean the simple resumption of past strategies of critical and radical practice, then radical social work is unlikely to experience a renaissance in the current cultural context. In this article, I explore several challenges to the efficacy of radical social work practice, starting with institutional and cultural shifts of the late 20th and early 21st centuries, and culminating in the failure of those projects seeking socio-political reform as the basis for the achievement of social justice.
Consistent with the theoretical orientation of Bailey and Brake's (1975) radical praxis, the thesis advanced here is that, in the absence of an adequate understanding of the changing socio-political context, social workers and educators risk disappointment great enough to lead to the dead-end of disengaged apathy, or worse, to becoming sacrificial lambs on an outdated altar of "heroic agency" (Marston \& McDonald, 2012). Ironically, such situations of professional alienation effectively align with managerial strategies for the containment of dissent.

The sociological analysis offered by Bauman (2000) through the interpretive lens of liquid modernity brings the contemporary sociopolitical context of social work practice into sharper focus. Modernity's phase change from solid to liquid is characterised by the phenomenon of a gradual dissolution of its institutional structures, and a subsequent reconfiguration of the bonds between
AOTEAROA NEW ZEALAND SOCIAL WORK 29(2), 45-55.

CORRESPONDENCE TO: Angelika Papadopoulos angelika.papadopoulos@ rmit.edu.au 
power and politics. For the providers of the welfare state's social benefits, this has been experienced as the disappearance of a world that is immutable and durable and which operates according to a law-like regularity. For the recipients of those benefits, the same phenomena are experienced as the dismantling of the public sphere, with the concomitant transfer and individualisation of responsibility. In tandem with the melting of the formerly solid institutions and safety nets of social welfare is the corporatisation and commodification of human existence configured ever more narrowly in the single dimension of increasing consumption.

Bauman (2000) conceptualised liquid modernity to give metaphorical expression to the expansion of global capitalism and its impacts, and to capture "the novelty of the present-day social condition" (p. 17) what it is about this iteration of modernity that differs so much that we need to revise our view of the world. In this sense, liquid modernity is a rejection of, and an attempt to displace, the theoretical frame postmodernity. Bauman considered the concept of postmodernity to offer a temporary utility, signalling a crisis in modernity, but remaining within and therefore preventing "...taking a distance to certain theorizing habits, cognitive frames, tacit assumptions sedimented in the wake of a century-long deployment of the 'modernity

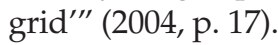

The implications of understanding liquid modernity for radical praxis include the possibility that strategies identified as radical in earlier contexts have become as impotent as the state in the face of the new social formations produced by globalised social relationships. For many years, Bauman described this state impotence as a consequence of "...the divorce of power from politics, and the shifting of functions once undertaken by political authorities sideways to the markets and downward to individual life-politics" (Bauman, 2010, p. 398).

While it is not argued here that social work ought to abandon its commitment to social change in the interests of a better world, an understanding of the politicoinstitutional features of our new social landscape can explain how it is that efforts to develop and enact a vision of this better world often culminate in apathy and disinterest (McKendrick \& Webb, 2014). Bauman and Bordoni (2014) identify the current crisis as one of agency experienced both at the level of the state and at the level of the individual, to which there can be a range of responses. One response is the retreat into apathy that concerns McKendrick and Webb (2014); another is the desire of social workers to achieve change through proposals to re-organise, re-collectivise and take back the power that has been yielded to corporations by the state.

In contrast to McKendrick and Webb's analysis, it is suggested here that this apathy is not because of the tendency of mainstream liberal social work to present a politically neutral face (and, in so doing, destabilise the solidarity of the profession) but, rather, it is because radical and critical perspectives are confronted with a structurally reformed terrain whose impasses are generated by the contradictory impulses internal to their own theoretical stance. This recontextualises what is intended and alters what is ultimately achieved by "taking a political stance". Accordingly, radical strategies need rethinking in the light of the profound changes in the institutional framework originally constituting the locus of intervention for radical projects. These changes are individualising in their intent and anti-collectivist in their effect, and it is in the context of this dynamic that the challenges for radical praxis are situated. These challenges are further compounded by the questioning of the emancipatory project from theoretical perspectives that are (sometimes unfairly) dismissed as mere postmodern relativism.

\section{Socio-political context}

Social work in Anglophone countries has been unsettled by changes in the socio- 
political contexts of practice. In Australia, these changes have taken such forms as increasingly conditional social security provision through "workfare" (for those of working age), reductions in the "social wage" (for example through increasing the age of eligibility for pensions for older people), persistent and egregious efforts to "reduce the costs" of the disability support pension (Porter, 2016), market-based provision of social services, persistent structural unemployment, and work intensification and precariousness (Rawling, 2015) for the employed. Pusey's (2003, p. 1) summation of the Australian experiment with economic reform "...deregulation, privatisation, labour market reform, micro-economic reform, user pays, tax reform, cutting government spending, more competition, privatisation, tax reform (the GST), welfare reform, and - the latest instalment-the creeping privatising of Medicare and of the universities" describes the first round of what he called "economic rationalism", a label now subsumed under the rubric neoliberalism as one of its strategies.

Subsequent developments have continued the deregulatory trajectory and complemented it with measures which, in effect, restrict and manage dissent (Hamilton \& Maddison, 2007; Marston \& McDonald, 2013). No state welfare institution has escaped the reforming zeal of market fundamentalism (Stiglitz, 2002) _ in education, health-care and social security-market solutions that imagine an informed sovereign consumer have normalised individualisation, and with it, provided fresh justification for the victim-blaming approaches so carefully and thoroughly denounced by Ryan (1971). One explanation of the syndrome of radical fatigue, disillusionment and apathy referred to above is that it is an essentially rational response by those who expended so much energy in the 1970s forging new possibilities, only to witness the apparent ease with which hard-won achievements have simply been overturned.

The emergent neoliberal approach has made apparent the previous dependence of social work on a benevolent state prepared to listen to its claims. It has discouraged the perception of social workers as agents of change who are able to influence policy formations (Marston \& McDonald, 2012; Mendes, 2003), bringing social work as a profession with a legitimate claim to autonomy into question. While these challenges are rarely put directly, continual "reforms" in the fields in which social workers practice have resulted in revisions of the scope and mandate of social work's role and a gradual shrinking of the space in which social workers are recognised as autonomous professionals (McDonald, 2006). In Australia, the national disability insurance scheme (NDIS), and the market vernacular in which this restructuring is framed, illustrates the consequences of individualisation of service provision for social workers. This is apparent in the un-bundling (i.e., functional specialisation and re-distribution) of roles formerly associated with social work service provision, and in its deceptive appearance of increased autonomy and "choice" in how people living with different abilities can organise support (Fawcett \& Plath, 2012; Yeatman, 2009).

Structural change attributable to the deployment of "new public management" has captured the analytical energies of social workers who, immersed in comprehending the constrained possibilities of the present, are themselves constrained in their imagination of possible futures (Hick \& Pozzuto, 2005). In Bauman's terms, social work is itself becoming liquid, and the uncertainty generated by change in the institutions of practice also infuses social work's own understanding of its scope and appropriate practices. Into this context of uncertainty enters the contest of perspectives over what is to be done.

\section{Radical social work}

As illustrated in the examples below, characteristics associated with radical practice for those engaged in its theorisation include a critique of the social control functions of the state and of social welfare 
practice, alliance with service users, sociopolitical (structural) analysis and advocacy, macro-practice in policy analysis, critique and development, community organisation and social activism under the banner of emancipation. Iokamidis (2016) describes the fundamental orienting impulse of radicalism in social work as follows:

... a radical concept historically refers to a political theory and practice that aims to understand the root causes of social problems. While appreciation of these causes and alleviation of their detrimental effects on people's lives are important dimensions of radical social work, what really differentiates it from mainstream approaches is its emphasis on action that aims at social change. (np)

Similarly, Baldwin (cited in Lavalette, 2011, p. 197) suggested five strategies for a contemporary radical practice: "making the political nature of social work explicit ... developing a critically reflective approach to organisation and practice...making alliances with service users ... developing a practice based on social justice ... [and] acting collectively".

Fook (2002) summarised the "basic elements of a critical approach" as:

...structural analysis of social, and personally-experienced problems, i.e. an understanding of how personal problems might be traced to socioeconomic structures, ... a commitment to emancipatory forms of analysis and action, ... a stance of social critique (including an acknowledgement and critique of the social control functions of the social work profession and the welfare system) ... [and] a commitment to social change. (p. 5)

In reflecting on her own radicalisation, Fook further identified a gendered dimension operating in the separation of radical theory and social work practice, an antipathy towards casework as inherently pathologising and victim blaming, and the related idea that only macro-level work was associated with social and structural change.

Ferguson and Lavalette (2014) associate the future possibilities for radical praxis with alignment to social movements, distilling the following characteristics of such social movements from different sources:

Social movements are organised collectives; they represent a constituency who are normally excluded from the political process, or whose demands are not considered adequately within the political arena. They challenge aspects of the present world (economic, social, environmental, political) and their impact on individuals, communities and groups. In the process they confront the entrenched power of the powerful in myriad ways. Their normal form of activity is some form of contentious collective action, which they undertake to have their voice heard, to challenge authority and to win their demands [emphasis added]. All manner of activities can be recorded as social movement activities: strikes and trade union actions, riots and occupations, demonstrations and public meetings. (Ferguson \& Lavalette, 2014, p. 138)

From the explications of radical practice above it is apparent that, at the heart of radical praxis lie the ideas that influence and change can be achieved through collectivism and collective engagement, and that what needs to be changed (and how) can be determined by structural analysis. Marston and McDonald (2012, p. 1035) note "...an important point of political action is to make hegemonic truths appear as neither inevitable nor natural, so that other possibilities might emerge". The "hegemonic truths" of radical practice include strategies of social action that had force and efficacy in the social protest movements of the 1970s, during which (some of) the cohort referred to as "baby boomers" utilised their time and energy 
by engaging in public protest. "Boomer activism", echoing revolutionary praxis and the general strike, aimed to mobilise a critical mass of bodies that would stand between the unjust exercise of power and those vulnerable to its impact. But to continue to promote approaches founded on the premise of the efficacy of collectivism is to fail to appreciate that key changes effected through globalisation and the subsequent reshaping of nation-state priorities actually amounts to:

... the end of the era of mutual engagement: between the supervisors and the supervised, capital and labour, leaders and their followers, armies at war. The prime technique of power is now escape, slippage, elision and avoidance, the effective rejection of any territorial confinement with its cumbersome corollaries of order-building, ordermaintenance and the responsibility for the consequences of it all as well as of the necessity to bear their costs. (Bauman, 2000, p. 11)

Both the reconfigured power relationships that characterise late modernity and the dynamic of strategic disengagement as a contemporary technique of domination create significant challenges for radical praxis. The first challenge is the disappearance of a clear adversary; in the radical social work of the 1970s it was clear that both the state and the market were root causes of social inequalities, with radical practice taking the form of the assertion of alternative forms of social and political organisation or else efforts to subvert state-sanctioned, policy-generated injustices. Through the processes of privatisation and partnership however, the state and the markets now overlap, blurring the field of possible social action. Even where a target for intervention is identified, the practices described by Bauman as "disengagement" nullify efforts to critically engage with the injustices that are created. Structural analyses of social ills impute an outdated determinate stability to social structures that are now the subject of liquid modern transformation. The target of radical intervention has become elusive. This new social landscape therefore calls into question the character of adversarial action as a means to achieve social change.

\section{Reorienting practice: critique as solvent}

Unfettered by social obligations implicit in the formulation of the welfare state as carrying some responsibility for the wellbeing of its citizens, the neoliberal state operates in a field of restricted influence, with one eye on the maintenance of social control and the other looking for opportunities to promote economic growth in the hope it will trickle down, or at least create temporary opportunities for employment that can be represented as successful economic management. As part of the maintenance of social control there has been a concerted effort to pre-empt the forms of social action that constituted the critical canon of strategy bequeathed by the apparent successes of past activists. The main target of neoliberalism as a negative political project identified by Bourdieu (1998, np) is "a programme of the methodical destruction of collectives". This orientation destabilises the very collective basis upon which the efficacy of the model of activism for social change bequeathed by the baby boomers rests and which is inherent in the conceptualisations of radical praxis considered above.

The collectivist strategies that preceded the rise of neoliberalism appeared to have success in relation to the goal of socio-political reform, but their foundation in a mistaken cultural absolutism has become increasingly apparent through their inability to prevent their subsequent erosion and retrenchment through deregulatory legislation. Collectivist strategies championed by advocates of neoradical practice in the 21st century (Ferguson, 2009; Iokamidis, 2013; Webb \& Gray, 2013) as signalling hope for a renewed social work politics (e.g., Occupy and related protest 
movements against global trade treaties) seem to have been singularly unsuccessful beyond achieving conscientization. To continue to suggest that action for social change can take this form might be described as courageous in the mode of heroic agency; the cultural form of demonstration and protest shortcircuits the need to historically re-situate our understanding of the new social landscape, in order to orient our own actions.

Bauman argued that the novelties that characterise liquid modernity in contrast to the "solid modernity" of the industrial revolution are the frailty of social bonds, the impermanence of the institutional and interpersonal fields that are a consequence of this frailty and the benefits of impermanence for people in a position to take advantage of the new flexibility of social forms. As with the melting of the polar ice-the material analogue of liquid modernity - the becoming liquid of institutions and other social relations is neither a uniform event nor is it apprehended universally.

Two consequences: firstly that what is considered just or unjust, radical or reactionary varies according to where one is situated in the social field, and secondly (and relatedly), that interpretation and intervention must therefore vary according to specific circumstances of each social field. Part of such a response requires the development of different cognitive frames with which to apprehend the opportunities and disbenefits of revised social arrangements. While conscientization is a precondition of politicisation, radical perspectives often assume and advocate a vision of social reality relying upon an epistemological certainty which is now undermined by the fluid conditions of liquid modernity, under which uncertainty has come to be a defining characteristic not only of our understanding of future strategic possibilities, but also of present dynamics.

Wacquant (2004) describes the role of critique as solvent of doxa (i.e., dogma); critical analysis contributes to the "defamiliarising of the familiar" that Bauman identified as the core of critical social science (Jacobsen \& Tester, 2013, np). Critical analysis in (and of) practice remains the main mechanism by which social workers understand the impact of policy and reflect on their actions. However, it is important to bear in mind that critique is not in the service of any one given set of values. The reshaping of the role and functions of the state illustrates the ways in which critique can also be mobilised to serve aims antithetical to the motivating aim of the critique. The critique of the welfare state by radical social workers and others as exclusionary, paternalistic, racist and sexist (McMahon, Thomson, \& Williams, 2000) served an unintended function useful to the neoliberal agenda in providing rationalisations for the retrenchment of state-provided social services. The concerns and strategies of radical social work sometimes dovetailed neatly with the libertarian and deregulatory tendencies of economic fundamentalist liberalism. For example, while ostensibly at odds, both oppose state control, and both are proponents of co-production or partnership approaches to service users, albeit with very different intentions. The implication of this convergence is that critique must be complemented by the articulation of goals that go beyond merely tackling the social ills identified through critique.

\section{The language of practice: locally absolute, globally relative}

In relating the story of the five-year search for a definition of social work that would be acceptable to a global membership, Iokamidis (2013, p. 188) condemns "epistemologically vague, abstract or a-political notions of social work" for risking complicity with oppressive social work practice. It is argued that, as long as social work in the form of contracted service delivery remains entangled with state priorities, the risk of the re-assertion of oppression facilitated by theoretical prevarication will prevail. 
This critique of epistemological vagueness also applies to radical praxis if conceived as an adversarial contest which can be won by the power of community organisation or social protest, for the "sides" in this contest remain ill-defined if our understanding of what counts as knowledge is vague enough to legitimate shifts of agenda according to convenience. Three decades of post-structural critique highlighting the vulnerability of utopian thought to totalitarian appropriation, and interrogating the power dynamics concealed behind assertions of universal truth, have culminated in a pervasive scepticism towards metanarratives (Lyotard, 1984), and this has been misconstrued and denounced as "postmodern relativism" by theorists seeking certainty (and hence power) construed according to the old absolutist paradigm (see Webb \& Gray, 2013, p. 16). Webb and Gray see postmodernism as a diversion distracting attention from and thus as unwitting accessory to the expansion of global corporate capitalism. The perspectivism that permeates the thought of liquid modernity is, however, importantly distinct from the mere relativism of the postmodern.

Under the new paradigm of a generalised relativity, the challenge we now face is how, on the one hand, to comprehend the complexities of multiple perspectives without reducing them to a simplistic and naive relativism, while on the other, to understand the opposite but equal naivety of the absolutist who uncritically takes their own perspective as absolute. To be sceptical is not equivalent to treating all narratives as equally valid (naive relativism), but rather to critically evaluate the perspective from which each narrative emerges, i.e., to evaluate perspectives not on the flawed basis of unchanging universals, but rather by seeking a balanced awareness of the differential forces in play in a given situation, as generated through the interactions of the fields of social and cultural influence which hold sway over our fluid reality in each and every situation. Comprehending perspectivist epistemology in contrast to absolutist epistemology thus entails the ongoing task of resisting the tacit re-assertion of absolutism which remains an unconscious tendency despite our understanding of its limitations.

The same dissolution explained by the thought of a liquid modernity can be seen to preoccupy efforts to reconcile a range of theoretical perspectives through their grouping together as critical and radical (Woodward, 2013). Just as neoliberalism can be seen as an absolutist metanarrative, the quest for an articulation of radical social work that comprehends all critical, emancipatory and socially dynamic perspectives can itself be understood as a quest for a metanarrative.

To construe the metanarrative of radical social work, not as a pure expression of absolute insight divorced from any will to power, but rather as a will to influence power relations, is to understand radical discourses as forces that resist the narrative strength of the dominant discourse of market liberalism and its absolutist assumptions. If such resistance is to be more than mere reaction, it must be oriented by a clear sense of the difference between the big picture and the local context. Our big picture is today one of global relativity, but our individual lives remain situated by our local absolutes, despite our knowledge that this absolute status does not apply on the global level. Ever since the slogan "think globally, act locally" became a cliché, there has been a growing realisation that our situation is in fact doubled, and that we must learn a new dexterity in thinking to balance the competing demands of ideas in tension. Local praxis is situated in face-to-face relationships between individuals and groups. Global forces by contrast are diffuse and impersonal energies flowing in streams following beds carved by ideologies, religions and cultures over centuries. To construe power relations as the situated expression of the balance of locally absolute but globally relative forces at any given point in time is to see the 
complexity inherent in any attempt to adopt and maintain a political stance.

The theory of social change underpinning revolutionary praxis is inherently teleological - it envisions an end point to the action, precipitating the desired change. Apathy and exhaustion are the inevitable consequence of this theory being repeatedly falsified in practice. Perhaps the most difficult challenge for radical praxis is in the idea that there is no objective end to conflict, no post-revolutionary promised land of perpetual peace. A defining characteristic of totalising metanarratives (including radical perspectives calling for structural reform) is an implicit "happily ever after" beyond which there is no further need for struggle, for the war is over and has been won by the "good", "just" or "true" (the dominant psychological Zeitgeist of the post-WWII west). Scepticism towards metanarratives can thus also be understood as a growing disenchantment with the very idea of a happily ever after as suspicion of totalising assumptions centred upon addressing a single axis of inequality-for example, that the redistribution of wealth in a more equitable form will result in the achievement of goals beyond which there will be no further need for struggle. The temptation of revolutionary thought is that there will be just one crisis, one event, and after this there will be something completely different.

For a discipline and practice that employs language as its primary tool, social work has been notably ambivalent regarding its theorisation of the ways in which language not only reflects the reality it seeks to transform, but is also implicated in its creation. This is shown in its ahistorical assertions of social justice as an inherently meaningful universal concept. Even at its fullest articulation, as the upholding of rights, participation, equity and access, discourses advocating social justice have asserted the meanings of key concepts as absolute, rather than understanding their semantic vulnerability to contextual shifts.
Poststructural critique targets naive advocacy that is premised on the assumption that simply pointing out an injustice will lead to its redress, showing instead how such criticism is subsumed within the language game of whose voice is dominant (McLaughlin, 2014). The premature rejection of poststructural critique has deprived radical social work of the linguistic turn it requires in order to become conscious of the ways in which its discursive decisions direct and orchestrate its own possibilities. The discourse of practice left uncritically examined will continue to produce examples of the appropriation of concepts-empowerment, social justice, even liberation-in policy that results in consequences that contradict the values thought to inhere in the concept (McLaughlin, 2014; Mearns, 2014).

\section{Navigating liquid modernity}

From Bauman's sociological perspective, liquid modernity is presented as the prevailing dynamic of contemporary post-industrial societies. The rapidly melting terrain in which social workers practice requires a new approach to the cartography of fluid social relations, as does the critical research which attempts to map the new flow of institutional dynamics in order to influence the direction of social change. An account of the policy mechanisms by which liquidity is engendered and responded to is a core activity of social work in the mode of critique. Social policies which act as an instrument of liquefaction through formally reconfiguring relationships and responsibilities between state, market and citizens/subjects are the starting point for the remapping of the reconfigured social landscape, and a critical point at which it remains possible to exercise influence without assuming a static new state of affairs, but rather understanding the dynamics of social influence and change.

A map of a location on land is a static representation of spatial relations between 
physical objects. A map of a fluid location, say an ocean or gaseous planet, indicates not objects but rather regions of stability within change: relatively stable currents in the ocean like the Gulf Stream, or stable bands of cyclonic activity like Jupiter's Red Spot. Describing fluid realities is less simple than describing static objects, and our descriptive tools are differential and comparative rather than indicative and generic.

It has been argued here that critical dimensions of a cartography for radical praxis include the development of social workers' understanding of language, an appreciation of the perspectival nature of our world views, and a long-term appreciation of social change and its dynamics.

It took thirty years for the ideological, political and policy frameworks of neoliberalism to become organised and prevalent. Radical praxis confronts, and is confronted by, a reformed capital which is less reliant on labour to achieve its goals, and which makes use of precarity and perpetual reform strategies to destabilise opposition. The reinterpretation of reality that is signalled by the elaboration of liquid modernity and its implications for social actors accounts for the lack of traction of radical social work as metanarrative.

\section{Reframing radical social work}

Lakoff's (2004) work on framing and metaphor is premised on recognising the fluidity of concepts in political discourse. On his analysis, the recent history of the organisation and development of the political discourse of what he describes as "conservatives", illustrates a deficiency in progressive political discourse. The resources invested in think-tanks and institutes dedicated to framing values in popular messages invoking specific cognitive frames stand in contrast to the single-issue advocacy that he sees as characteristic of progressive politics. He identifies principles of framing through his analysis of the success of political conservatives in framing their values and ideas according to metaphors that have been attractive to voters, proposing that these principles would enable the development of a progressive framing of ideas and values that have common ground with the concerns of radical social work.

Lamenting the tendency of "progressives" to argue against ideas framed in their opponents' values, Lakoff illustrates the primary lesson of framing when he instructs his reader "don't think of an elephant", noting that an elephant inevitably comes to mind in order to be negated. The first lesson of framing is that negating a frame invokes and reinforces the frame it seeks to negate.

Radical social work developed and was framed in a socio-political context that supported-or at least tolerated-dissenting voices. As detailed in the preceding discussion, this context has shifted dramatically: power and politics have been separated through globalisation; institutions that were once the target of radical reform are themselves in flux; and social work remains at risk of recuperation by the neoliberal agenda. Marked by increasing intolerance of difference of all kinds, the contemporary context is hostile to radical perspectives.

In Australia, to describe one's activities as radical is to risk misidentification and marginalisation. This is because the frame radical social work not only invokes associations which in the post 9/11 world have become suspect through their mere cognitive resonance with other forms of radicalism, but also because it positions radical social workers as outside of something which they themselves identify as part of the problem, specifically, a mainstream liberal social work.

Radical social praxis does not necessarily depend on the existence of a metanarrative, and in fact can proliferate regardless of its theorisation in the educational context of debates regarding how social work ought to conduct itself in response to the dominant metanarrative of neoliberalism. This is to 
distinguish the discourse that identifies itself as radical social work from radical praxis, which follows as the consequence of situated analyses of practice in relation to current policy formations.

Resistance to the neoliberal metanarrative continues in many different forms (see for example, Carey \& Foster, 2011; Greenslade, McAuliffe, \& Chenoweth, 2015), however, there are reasons to doubt that achieving solidarity through conversion of the global profession of social work to the metanarrative of radical social work would even be sufficient to effect significant change in current dynamics. On this analysis it may, in fact, be the case that mainstream liberal social work has an important part to play in defending social work's very existence without which more radical debate is simply impossible.

In his poetic critique of the distractions of consumer culture, Gil Scott-Heron announced, "The revolution will not be televised. The revolution will be live". Radical practice resisting the hubris of "televising" itself stands a better chance of avoiding being targeted from both within and without the social work profession. The values enacted by radical projects are too important to be made vulnerable to the vicissitudes of political fashion. The thought of liquid modernity calls into question the idea of "taking a political stance" as the orienting strategy of future radical praxis because, in conditions of fluidity, a dynamic balance can succeed in navigating the turbulence surrounding the interface of the global and the national, where unyielding resistance cannot.

\section{References}

Bailey, R., \& Brake, M. (1975). Radical social work. London, UK: Edward Arnold.

Bauman, Z. (2000). Liquid modernity. Cambridge, UK: Polity Press.

Bauman, Z. (2004). Liquid sociality. In N. Gane (Ed.) The future of social theory (pp. 17-34). London, UK: Continuum.

Bauman, Z. (2010). Education in the world of diasporas. Policy Futures in Education, 8(3-4), 398-407.

Bauman, Z., \& Bordoni, C. (2014). State of crisis. Cambridge, UK: Polity Press.
Bourdieu, P. (1998). The essence of neoliberalism. Le Monde Diplomatique. Retrieved from http://mondediplo.com/1998/12/08bourdieu

Carey, M., \& Foster, V. (2011). Introducing "deviant" social work: Contextualising the limits of radical social work whilst understanding (fragmented) resistance within the social work labour process. British Journal of Social Work, 41, 576-593. doi:10.1093/bjsw/bcq148 [Advance Access publication February 2, 2011].

Fawcett, B., \& Plath, D. (2012). A national disability insurance scheme: What social work has to offer. British Journal of Social Work [first published online October 7, 2012]. doi:10.1093/bjsw/bcs141

Ferguson, I. (2009). Another social work is possible! Reclaiming the radical tradition. In V. Leskoše (Ed.), Theories and methods of social work: Exploring different perspectives (pp. 81-98). Ljubljana, Slovenia: University of Ljubljana Faculty of Social Work.

Ferguson, I., \& Lavalette, M. (2014). Editorial. Critical and Radical Social Work, 2(2), 137-140.

Fook, J. (2002). Social work: Critical theory and practice. London, UK: Sage.

Greenslade, L., McAuliffe, D., \& Chenoweth, L. (2015). Social workers' experiences of covert workplace activism. Australian Social Work, 68(4), 422-437. doi:10.1080/0312407X.2014.940360

Hamilton, C., \& Maddison, S. (2007). Silencing dissent. Crows Nest, NSW: Allen \& Unwin.

Heraclitus http://www.heraclitusfragments.com/files/ge.htm/

Hick, S., \& Pozzuto, R. (2005). Introduction: Towards "becoming" a critical social worker. In S. Hick, J. Fook, \& R. Pozzuto (Eds.), Social work: A critical turn (pp. ix-xviii). Toronto, ONT: Thompson Education Publishing.

loakimidis, V. (2013). Beyond the dichotomies of cultural and political relativism: Arguing the case for a social justice based "global social work" definition. Critical and Radical Social Work, 1(2), 183-199.

loakimidis, V. (2016, May 24). A guide to radical social work. The Guardian. Retrieved from https://www.theguardian. com/social-care-network/2016/may/24/radical-socialwork-quick-guide-change-poverty-inequality

Jacobsen, M. H., \& Tester, K. (2013, April). De-familiarize the familiar and familiarize the unfamiliar: Interview with Zygmunt Bauman. The Essayist. Retrieved from http://www.the-essayist.org/2013/04/de-familiarize-thefamiliar-and-familiarize-the-unfamiliar/

Lakoff, G. (2004). Don't think of an elephant! Know your values and frame the debate: The essential guide for progressives. White River Junction, VT: Chelsea Green Publishing.

Lavalette, M. (Ed.). (2011). Radical social work today: Social work at the crossroads. Bristol, UK: Policy Press.

Lyotard, J. F. (1984). The postmodern condition: A report on knowledge. Manchester, UK: Manchester University Press.

Marston, G., \& McDonald, C. (2012). Getting beyond "heroic agency" in conceptualising social workers as policy actors in the twenty-first century. British Journal of Social Work [first published online May 24, 2012]. doi:10.1093/ bjsw/bcs062 
Marston, G., \& McDonald, C. (2013). The Australian welfare state: Who benefits now? Melbourne, VIC: Palgrave Macmillan.

McDonald, C. (2006). Challenging social work: The institutional context of practice. London, UK: Palgrave Macmillan.

McKendrick, D., \& Webb, S. A. (2014). Taking a political stance in social work. Critical and Radical Social Work, 2(3), 357-369. doi:10.1332/204986014×14096553584619

McLaughlin, K. (2014). Empowering the people: 'empowerment' and the British Journal of Social Work, 1971-99. Critical and Radical Social Work 2 (2), $203-216$.

McMahon, A., Thomson, J., \& Williams, C. (Eds.). (2000). Understanding the Australian welfare state: Key documents and themes. Croydon, VIC: Tertiary Press.

Mearns, G. (2014). The neoliberal agenda and social work values: using critical discourse analysis to explore the role of language in processes of cultural hegemony. Critical and Radical Social Work 2 (2), 217 - 233.

Mendes, P. (2003). Social workers and social action: A case study of the Australian Association of Social Workers' Victorian branch. Australian Social Work, 56, 16-27. doi:10.1046/j.0312-407X.2003.00053.x

Porter, C. (2016). Investing in people-improving lives. Media release, Department of Social Services, 20 September 2016. Retrieved from http://christianporter. dss.gov.au/media-releases/investing-in-peopleimproving-lives

Pusey, M. (2003). An Australian story: The troubling experience of economic reform. Presented as a lecture in the Department of the Senate Occasional Lecture Series at Parliament House on 20 June 2003. Retrieved from http://www.aph.gov.au/binaries/senate/pubs/pops/ pop40/pusey.pdf

Rawling, M. (2015). Regulating precarious work in Australia: A preliminary assessment. Alternative Law Journal, 40(4), 252-256.

Ryan, W. (1971). Blaming the victim. New York, NY: Pantheon Books.

Scott-Heron, G. (1970). The revolution will not be televised. Retrieved from https://genius.com/Gil-scott-heronintroduction-the-revolution-will-not-be-televisedannotated

Stiglitz, J. (2002). Globalisation and its discontents. New York, NY: W. W. Norton \& Company.

Wacquant, L. (2004). Critique as solvent of doxa Constellations, 11(1), 97-101. doi: 10.1111/j.13510487.2004.0034.x

Webb, S., \& Gray, M. (2013). The new politics of social work. London, UK: Palgrave Macmillan.

Yeatman, A. (2009). Individualization and the delivery of welfare services: Contestation and complexity. London, UK: Palgrave Macmillan.

Woodward, R. (2013). Some reflections on critical and radical social work literature. Critical and Radical Social Work, 1(1), 135-140. 